\title{
PERILAKU REMAJA TERHADAP PENGGUNAAN ORTODONTI CEKAT PADA SISWA SMA DON BOSCO PADANG
}

\author{
Addientya Maykeza ${ }^{1}$, Rizanda Machmud², Lendrawati ${ }^{1}$ \\ ${ }^{1}$ Fakultas Kedokteran Gigi Universitas Andalas \\ ${ }^{\mathbf{2}}$ Fakultas Kedokteran Universitas Andalas
}

\begin{abstract}
Nowadays, the shifting of fixed orthodontic function becomes a lifestyle is more popular than before. The study is purpose to determine a relationship between teenager behaviour (knowledge, attitudes, and action) to fixed orthodontic appliance.This study using cross sectional study design. The sample was a high school students of Don Bosco Padang, Sumatera Barat. The number of samples are 90 people, that chosen by proportionate stratified random sampling technique. The data was collected by using a questionnaire to measure the level of knowledge, attitude and action. Data analysis using Chi-Square test. The result showed there was no significant relationship between teenager knowledge, attitude, and action with fixed orthodontic application in high school students of Don Bosco Padang. The conclusion from this study is that most of high school students of Don Bosco Padang have a high knowledge, positive attitude, and good action about fixed orthodontic treatment.
\end{abstract}

Keywords: knowledge, attitude, action, fixed orthodontic

Affiliasi penulis: ${ }^{1}$ Fakultas Kedokteran Gigi Universitas Andalas Korespondensi: lendrawati, email: drglendrawati@gmail.com

\section{PENDAHULUAN}

Ortodonti pada awalnya dapat diartikan sebagai cabang ilmu kedokteran gigi yang berkenaan dengan variasi genetik, pertumbuhan dan perkembangan wajah serta berbagai faktor yang mempengaruhi oklusi geligi dan fungsi berbagai organ yang terkait. Rintisan ortodonti era modern dimulai pada tahun 1723 ketika Pierre Fauchard di Perancis membuat bandolet untuk menata letak gigi. Kemudian pada tahun 1850 Norman Williams Kingsley di Amerika Serikat menulis Oral Deformities yang berisi etiologi, diagnosis dan perawatan kelainan letak gigi. Edward H. Angle menyempurnakannya dengan menciptakan peranti ortodonti dan klasifikasi maloklusi yang kita pakai hingga saat ini. Tujuan perawatan ortodonti sendiri adalah untuk memperbaiki letak gigi dan rahang yang tidak normal sehingga didapatkan fungsi geligi dan estetik geligi yang baik maupun wajah yang estetis dan bertujuan untuk meningkatkan kesehatan psikososial seseorang. ${ }^{1}$

$$
\text { Perawatan ortodonti telah }
$$
dikenal sejak lama, hanya saja terdapat perbedaan antara ortodonti dimasa sebelumnya dan dimasa kini. Adanya dukungan perkembangan sistem informasi terkini yang semakin pesat, menyebabkan pengetahuan masyarakat tentang fungsi ortodonti pun berubah, 
tetapi tidak berarti meninggalkan fungsi lamanya, yaitu bermanfaat dalam konteks kesehatan. Perubahan yang dimaksud adalah trend lifestyle atau sebatas gaya hidup semata. Meski demikian, tidak dapat dipahami jika perubahan dari fungsi kesehatan menuju fungsi lifestyle tersebut bertujuan agar penampilan menjadi lebih menarik, sebab keduanya tentu mengarah pada penampilan. $^{2}$

Penilaian akan kebutuhan perawatan ortodonti memerlukan suatu pengertian yaitu bahwa tanpa perawatan, maloklusi atau kelainan dentofasial akan berakibat negatif. Keadaan negatif tidak akan terjadi jika kondisi tersebut dirawat atau dikembalikan ke posisi dan fungsi normalnya. Kekhawatiran terhadap dampak negatif, pengaruh keadaan sosial dan budaya serta pengaruh pemasaran memainkan peran yang besar dalam menentukan rasa membutuhkan perawatan. Shaw dkk melakukan studi penelitian dengan menggunakan kuesioner kepada orang tua yang anaknya mendapat perawatan ortodonti. Ia menemukan persentase yang tinggi pada orang tua yang mengharapkan manfaat positif dari perawatan ortodonti. Lebih dari $70 \%$ responden percaya bahwa susunan gigi yang rapi akan menyebabkan anaknya lebih menarik dan lebih cantik, dan $75 \%$ merasa bahwa perawatan ortodonti penting untuk keberhasilan kedudukan anaknya di masa depan. Mendekati $90 \%$ merasa bahwa gigi yang rapi itu penting bagi kesehatan gigi anaknya. ${ }^{3}$

WHO (World Health

Organization) telah mengukur prevalensi kebutuhan akan perawatan ortodonti berkisar antara 21\% - 64\% (Burden, 1995). Di Indonesia, Agusni (1998) melakukan penelitian pada anak sekolah dasar di Surabaya yang hasilnya menunjukkan bahwa $31 \%$ anak tidak memerlukan perawatan terhadap maloklusi, $45 \%$ anak memerlukan perawatan ringan, dan $24 \%$ anak sangat memerlukan perawatan ortodonti karena keadaan maloklusi yang tergolong parah sehingga dapat mengganggu kesehatan fisik dan kehidupan sosialnya. ${ }^{4}$

Data survei epidemiologi USPHS (United States of Public Health Service) menggambarkan bahwa kurang lebih 35\% remaja di Amerika masih dianjurkan oleh orang tuanya untuk merawatkan giginya dan dibiayai perawatan giginya, sedangkan yang $20 \%$ lainnya dianjurkan oleh dokter giginya. Jika persepsi kebutuhan dipengaruhi oleh ketersediaan pelayanan dan SDM, maka diharapkan bahwa orang-orang yang tinggal di suatu tempat dimana pelayanan perawatan ortodonti tersedia dan memadai akan merasa lebih besar kebutuhannya akan perawatan daripada orang-orang yang berada di daerah 
dimana pelayanan ortodontinya kurang ditekankan. ${ }^{3}$

Berdasarkan penelitian yang dilakukan oleh Tandriano (2012) di kota Makassar, penyebaran informasi yang pesat dapat dikatakan sebagai penyebab tingginya penggunaan ortodonti. Penyebaran informasi berupa berita di media cetak maupun elektronik yang dapat membentuk pengetahuan remaja, sekaligus merubah pendapat tentang penampilan diri. Hasilnya menunjukkan bahwa para remaja yang berprofesi sebagai mahasiswa dan mahasiswi mengetahui informasi tentang ortodonti dari interaksi antar sesama mereka, dan sebagian dari mereka memutuskan untuk menggunakan ortodonti setelah mendapat informasi atau tambahan pengetahuan dari pihak keluarga. Status sosial ekonomi dari individu juga mempengaruhi pemakaian ortodonti cekat, dimana pengguna ortodonti cekat adalah mereka yang memiliki status ekonomi menengah ke atas, dengan tingkat interaksi antar sesama dan penerimaan informasi sangat tinggi. ${ }^{2}$

Bagi pasien-pasien yang masih muda biasanya alasan mengenai pelayanan ortodonti berasal dari dokter gigi keluarga dan keikut-sertaan orang tuanya. Setelah anak meningkat menjadi dewasa, mereka menjadi lebih peka terhadap pengaruh teman-temannya, terutama apabila teman-temannya juga mendapat perawatan orthodonti. Bagi pasien-pasien dewasa, perhatian dalam pelayanan ortodonti dapat berasal dari membaca artikel-artikel dalam majalah, melihat dan mendengarkan TV dan radio, dan membaca surat kabar. ${ }^{3}$

Berdasarkan survei pendahuluan yang sudah dilakukan di SMA Don Bosco Padang pada bulan Mei 2013, didapat sebanyak 82 orang dari 579 total siswa kelas 1 dan $2( \pm 15 \%)$ memakai peranti ortodonti cekat. Ini pula yang menjadi salah satu alasan penulis untuk mengetahui perilaku (pengetahuan, sikap dan tindakan) siswa SMA Don Bosco Padang tentang ortodonti cekat, dan faktor yang mempengaruhi kebutuhan perawatan ortodonti berdasarkan kualitas pelayanan gigi, ketersediaan pelayanan, perkembangan teknik perawatan, gaya hidup, dan sumber daya ekonomi yang tersedia untuk membiayai perawatan ortodonti. ${ }^{3}$

\section{METODE}

Kajian dalam penelitian ini adalah perilaku yang mencakup hubungan pengetahuan, sikap, dan tindakan terhadap penggunaan ortodonti cekat. Kajian ini menggunakan rancangan penelitian analitik observasional dengan metode cross sectional. Sampel dalam penelitian diambil dengan menggunakan teknik Proportionate Stratified Random 
Sampling. Teknik pemilihan acak ini dilakukan dengan cara undian menggunakan lotere berdasarkan kronologi nomor urut absen. Analisis univariat dilakukan untuk melihat distribusi frekuensi dari masing-masing variabel independen (pengetahuan remaja tentang ortodonti cekat, sikap remaja terhadap penggunaan ortodonti cekat, dan tindakan remaja terhadap penggunaan ortodonti cekat) pada siswa SMA Don Bosco Padang dan variabel dependen (penggunaan ortodonti cekat). Hubungan tingkat pengetahuan, sikap, dan tindakan remaja terhadap penggunaan ortodonti cekat pada siswa SMA Don Bosco dilakukan uji statistik menggunakan uji Chi-square.

\section{HASIL DAN PEMBAHASAN}

Pada penelitian ini berdasarkan karakteristik jenis kelamin diketahui sebagian besar yang menjadi responden adalah perempuan dengan jumlah 60 siswa $(66,7 \%)$ dan laki- laki berjumlah 30 siswa (33,3\%). Gambaran pengetahuan siswa SMA Don Bosco Padang, dimana siswa yang memiliki pengetahuan dengan kategori tinggi berjumlah 76 siswa $(84,4 \%)$ dan 14 siswa $(15,6 \%)$ yang memiliki pengetahuan rendah tentang perawatan ortodonti cekat. Secara garis besar dari total 90 responden, siswa yang memiliki pengetahuan rendah mengenai lama perawatan ortodonti cekat sebanyak 54 siswa $(60 \%), \quad 53$ siswa $\quad(58,9 \%)$ berpengetahuan rendah mengenai efek samping penggunaan ortodonti cekat, 49 siswa $(54,4 \%)$ memiliki pengetahuan yang rendah mengenai fungsi ortodonti cekat, dan 28 siswa $(31,1 \%)$ memiliki pengetahuan yang rendah mengenai tingkat kepentingan dalam penggunaan ortodonti cekat.

Gambaran sikap siswa SMA Don Bosco Padang terhadap perawatan ortodonti cekat, dimana 50 siswa $(55,6 \%)$ memiliki sikap positif, dan 40 siswa $(44,4 \%)$ memiliki sikap negatif dari total 90 responden. Secara garis besar dari total 90 responden, sebanyak 49 siswa $(54,4 \%)$ memiliki sikap negatif dalam pemeliharaan oral hygiene bagi pengguna ortodonti cekat, 31 siswa $(34,4 \%)$ memiliki sikap negatif dalam konteks penggunaan ortodonti cekat tanpa dipengaruhi biaya perawatan, dan sebanyak 29 siswa $(32,2 \%)$ memiliki sikap negatif dalam hal pemasangan ortodonti cekat ke dokter gigi ahli.

Gambaran tindakan siswa SMA Don Bosco Padang tentang perawatan ortodonti cekat dimana sebanyak 69 siswa $(76,7 \%)$ memiliki tindakan yang baik dan 21 siswa $(23,3 \%)$ tindakannya kurang baik terhadap perawatan ortodonti cekat. Secara garis besar dari total 90 responden, sebanyak 62 siswa $(68,9 \%)$ memiliki tindakan yang kurang 
baik dalam memperhatikan fungsi medis ortodonti cekat daripada fungsi lifestyle, 44 siswa $(48,9 \%)$ memiliki tindakan yang kurang baik dalam pemasangan ortodonti cekat ke dokter gigi ahli tanpa dipengaruhi ekonomi, dan sebanyak 36 siswa $(40,0 \%)$ memiliki tindakan yang kurang baik dalam hal lama pemakaian ortodonti cekat yang sesuai rencana perawatan.

$$
\text { Hasil tabulasi silang }
$$
menunjukkan bahwa persentase 85,7\% responden memiliki pengetahuan yang rendah tentang perawatan ortodonti cekat tetapi tidak menggunakan alat ortodonti cekat, $88 \%$ responden memiliki sikap positif terhadap perawatan ortodonti cekat tetapi tidak menggunakan alat ortodonti cekat. 84,1 $\%$ responden memiliki tindakan yang baik terhadap perawatan ortodonti cekat dan tidak menggunakan alat ortodonti cekat. Hasil analisis dengan menggunakan chi-square menunjukkan bahwa tidak terdapat hubungan yang bermakna antara pengetahuan, sikap, dan tindakan terhadap perawatan ortodonti cekat dengan penggunaan ortodonti cekat $(\mathrm{P}>0.05)$.

Pengetahuan seseorang dapat diperoleh melalui informasi seperti media cetak dan media elektronik. ${ }^{5}$ Pengetahuan diperoleh setelah seseorang melakukan penginderaan terhadap suatu obyek tertentu, meliputi indera penglihatan, pendengaran, penciuman, rasa dan raba. Sebagian besar pengetahuan manusia diperoleh melalui mata dan telinga. ${ }^{6}$

Dari hasil penelitian, diperoleh gambaran pengetahuan siswa tentang perawatan ortodonti cekat, yang memiliki pengetahuan dengan kategori tinggi berjumlah 76 siswa $(84,4 \%)$, dan 14 siswa $(15,6 \%)$ memiliki pengetahuan rendah tentang perawatan ortodonti cekat. Jenis pengetahuan responden tentang perawatan ortodonti cekat juga dapat dinilai berdasarkan jawaban benar dan salah dalam kuesioner. Hasil yang diperoleh adalah siswa yang memiliki pengetahuan rendah mengenai lama perawatan ortodonti cekat sebanyak 54 siswa $(60 \%), 53$ siswa $(58,9 \%)$ memiliki pengetahuan rendah mengenai efek samping penggunaan ortodonti cekat, 49 siswa $(54,4 \%)$ memiliki pengetahuan yang rendah mengenai fungsi ortodonti cekat, dan 28 siswa $(31,1 \%)$ memiliki pengetahuan yang rendah mengenai tingkat kepentingan dalam penggunaan ortodonti cekat.

$$
\text { Pembentukan pengetahuan }
$$
remaja mengenai ortodonti cekat dewasa ini dapat disebabkan oleh faktor pergaulan dan media. Penyebaran informasi terjadi dari interaksi antar sesama di berbagai kesempatan yang menunjukkan bahwa para remaja mengetahui informasi tentang ortodonti 
cekat dari interaksi antar sesama mereka, sebagian dari mereka memutu skan untuk menggunakan ortodonti cekat setelah mendapat informasi atau tambahan pengetahuan dari pihak keluarga. Melalui media, penyebaran informasinya dapat berupa berita di media cetak (melalui koran atau majalah) maupun elektronik (melalui tayangan seputar kesehatan mulut dan gigi, termasuk pula liputan tentang artis yang menggunakan kawat gigi). Dengan demikian informasi yang diterima dapat berupa tulisan dan dapat pula berupa gambar, yang dapat membentuk pengetahuan remaja sekaligus merubah pendapat tentang penampilan diri. ${ }^{2}$

Menurut Green dalam Notoatmodjo (2007), pengetahuan menjadi salah satu faktor predisposisi yang mempengaruhi perilaku seseorang atau masyarakat terhadap kesehatan. Jika masyarakat tahu apa saja pelayanan kesehatan, maka kemungkinan masyarakat akan menggunakan fasilitas kesehatan juga akan berubah seiring dengan pengetahuan seperti apa yang diketahuinya. $^{7}$

Sikap merupakan reaksi atau respon yang masih tertutup dari seseorang terhadap suatu stimulus atau objek. Sikap belum merupakan suatu tindakan atau aktifitas, akan tetapi adalah merupakan predisposisi tindakan atau perilaku. ${ }^{6}$ Menurut Maramis (cit.
Gaol, 2013), sikap dapat dianggap sebagai suatu predisposisi umum untuk berespons atau bertindak secara positif atau negatif terhadap suatu objek atau orang disertai emosi positif atau negatif. Dengan kata lain sikap perlu penilaian positif, negatif dan netral tanpa reaksi afektif apapun. Sikap dipengaruhi oleh kepribadian, pengalaman, pendapat umum, dan latar belakang. Sikap mewarnai pandangan terhadap seseorang terhadap suatu objek, memengaruhi perilaku dan relasi dengan orang lain. Untuk bersikap harus ada penilaian sebelumnya. Sikap bisa baik atau tidak baik. Perasaan sering berakar dalam sikap dan sikap dapat diubah. Sikap biasanya sedikit atau banyak berhubungan dengan kepercayaan. Dalam beberapa hal sikap merupakan akibat dari suatu kumpulan kepercayaan. ${ }^{8}$ Menurut Azwar (2009), sumber daya dan budaya menjadi salah satu faktor pendukung seseorang untuk bersikap positif atau negatif terhadap objek atau stimulus tertentu. ${ }^{9}$

Hasil penelitian menunjukkan gambaran sikap siswa SMA Don Bosco Padang terhadap perawatan ortodonti cekat, dimana 50 siswa $(55,6 \%)$ memiliki sikap positif, dan 40 siswa $(44,4 \%)$ memiliki sikap yang negatif terhadap perawatan ortodonti cekat. Berdasarkan jawaban benar dan salah dalam kuesioner, jenis sikap responden 
terhadap perawatan ortodonti cekat diperoleh hasil secara garis besar bahwa sebanyak 49 siswa $(54,4 \%)$ memiliki sikap negatif dalam pemeliharaan oral hygiene bagi pengguna ortodonti cekat, 31 siswa $(34,4 \%)$ memiliki sikap negatif dalam konteks penggunaan ortodonti cekat tanpa dipengaruhi biaya perawatan, dan sebanyak 29 siswa $(32,2 \%)$ memiliki sikap negatif dalam hal pemasangan ortodonti cekat ke dokter gigi ahli.

Keputusan untuk menggunakan ortodonti cekat sepatutnya memiliki alasan yang tepat. Masa pertumbuhan adalah masa yang tepat bagi seseorang untuk menggunakan ortodonti cekat, dimana jika orang tersebut memang memiliki susunan geligi yang tidak normal dalam pengertian kedokteran atau kesehatan, maka wajar untuk menggunakan piranti tersebut. Sebaliknya jika hanya untuk style, sebenarnya tidak diperlukan sebab ortodonti cekat telah memiliki fungsi ganda yakni untuk menambah ketertarikan atau mengarah pada penampilan. $^{2}$

Pengetahuan dan sikap sangat penting untuk terbentuknya tindakan seseorang. Pengetahuan akan mempengaruhi seseorang dalam mengadopsi perilaku dan suatu sikap yang dilaksanakan secara nyata disebut tindakan, namun suatu sikap belum otomatis terwujud dalam suatu tindakan (overt behavior). Untuk terwujudnya sikap untuk menjadi suatu perbuatan nyata diperlukan faktor pendukung atau suatu kondisi yang memungkinkan. ${ }^{6}$ Menurut Dever (cit. Saragih, 2003) bahwa teknologi yang digunakan dalam pelayanan kesehatan, norma dan nilai sosial serta keyakinan yang ada di masyarakat akan mempengaruhi seseorang didalam bertindak, termasuk dalam menggunakan pelayanan kesehatan. ${ }^{10}$

Hasil penelitian menunjukkan gambaran tindakan siswa SMA Don Bosco Padang terhadap perawatan ortodonti cekat, dimana sebanyak 69 siswa $(76,7 \%)$ memiliki tindakan yang baik, dan 21 siswa $(23,3 \%)$ tindakannya kurang baik terhadap perawatan ortodonti cekat. Berdasarkan jawaban benar dan salah dalam kuesioner, jenis tindakan responden terhadap perawatan ortodonti cekat diperoleh hasil secara garis besar bahwa sebanyak 62 siswa $(68,9 \%)$ memiliki tindakan yang kurang baik dalam memperhatikan fungsi medis ortodonti cekat daripada fungsi lifestyle, 44 siswa $(48,9 \%)$ memiliki tindakan yang kurang baik dalam pemasangan ortodonti cekat ke dokter gigi ahli tanpa dipengaruhi ekonomi, dan sebanyak 36 siswa (40,0\%) memiliki tindakan yang kurang baik dalam hal lama pemakaian 
ortodonti cekat yang sesuai rencana perawatan.

Dari hasil penelitian, diperoleh gambaran pengetahuan, sikap, dan tindakan siswa terhadap penggunaan ortodonti cekat secara garis besar diantaranya 63 siswa memiliki pengetahuan yang tinggi tentang perawatan ortodonti cekat dan tidak menggunakan alat ortodonti cekat, 44 siswa memiliki sikap yang positif terhadap perawatan ortodonti cekat dan tidak menggunakan alat ortodonti cekat, 58 siswa memliki tindakan yang baik terhadap perawatan ortodonti cekat dan tidak menggunakan alat ortodonti cekat.

Penelitian Setyawan (2007) menyatakan ada hubungan antara sikap dan minat masyarakat untuk memanfaatkan sarana pelayanan kesehatan modern yang berkaitan dengan faktor-faktor pendukung antara lain biaya pengobatan, hasil pengobatan, kepercayaan kepada sarana pengobatan, kondisi waktu berobat, keberadaan sarana, pelayanan pengobatan dan situasi di sarana pengobatan serta konsep sehat dan sakit yang dimiliki oleh masyarakat. Menurut WHO (1999) salah satu faktor yang menyebabkan seseorang berperilaku dalam hal pemanfaatan pelayanan kesehatan adalah sumber daya dan sumber dana yang dimiliki, antara lain kesempatan dan kemampuan membayar. ${ }^{8}$
Dari hasil penelitian mengenai hubungan pengetahuan, sikap dan tindakan remaja terhadap penggunaan ortodonti cekat, diperoleh hasil analisis dengan menggunakan chi-square menunjukkan nilai $\mathrm{P}>0.05$. Hal ini menunjukkan tidak terdapat hubungan yang bermakna antara pengetahuan, sikap dan tindakan remaja terhadap penggunaan ortodonti cekat. Ini bisa disebabkan karena sebagian besar responden tidak memiliki kelainan maloklusi dan mereka tidak membutuhkan perawatan ortodonti cekat namun memiliki pengetahuan yang sangat baik mengenai perawatan ortodonti cekat. Sebagian besar responden yang memiliki pengetahuan, sikap dan tindakan yang baik, memungkinkan mereka untuk mengetahui apakah diri mereka sendiri memerlukan perawatan tersebut atau tidak, karena mereka mengetahui tujuan serta fungsi dari ortodonti cekat. Pengambilan tindakan dalam pemasangan ortodonti cekat selain dipengaruhi oleh faktor pengetahuan, juga dipengaruhi oleh beberapa faktor lain seperti faktor sosial ekonomi. Responden menyadari bahwa mereka membutuhkan perawatan ortodonti cekat, namun terhalang oleh masalah ekonomi sehingga mereka tidak bisa menggunakan ortodonti cekat. Faktor sosial ekonomi disini berperan penting 
karena menentukan apakah seseorang tersebut sanggup memasang ortodonti cekat ke dokter gigi ahli yang biaya perawatannya sangat mahal.

\section{SIMPULAN}

Sebagian besar siswa SMA Don Bosco Padang tidak menggunakan alat ortodonti cekat dan hanya sedikit diantaranya yang menggunakan alat ortodonti cekat dengan tingkat pengetahuan yang tinggi, sikap yang positif, dan tindakan yang baik tentang perawatan ortodonti cekat. Sebagian besar siswa memiliki pengetahuan yang rendah rendah mengenai lama perawatan ortodonti cekat, efek samping penggunaan ortodonti cekat, fungsi ortodonti cekat, dan tingkat kepentingan dalam penggunaan ortodonti cekat; memiliki sikap negatif dalam pemeliharaan oral hygiene bagi pengguna ortodonti cekat, kemudian dalam hal penggunaan ortodonti cekat tanpa dipengaruhi biaya perawatan, serta dalam hal pemasangan ortodonti cekat ke dokter gigi ahli; serta memiliki tindakan yang kurang baik dalam hal memperhatikan fungsi medis ortodonti cekat daripada fungsi lifestyle, kemudian dalam hal pemasangan ortodonti cekat ke dokter gigi ahli tanpa dipengaruhi ekonomi, serta dalam hal lama pemakaian ortodonti cekat yang sesuai rencana perawatan. Sehingga dapat disimpulkan bahwa tidak terdapat hubungan yang bermakna antara pengetahuan, sikap dan tindakan remaja terhadap penggunaan ortodonti cekat.

\section{KEPUSTAKAAN}

1. Pambudi Raharjo. Ortodonti Dasar. Edisi Pertama. 2009. Airlangga University Press. Surabaya

2. Tandriano, T. Skripsi: BEHEL (Studi Antropologi Tentang Citra Diri Remaja Pengguna Kawat Gigi di Kota Makassar. 2012. Diakses pada tanggal 12 Oktober 2012 .Soendoro T.. Laporan Hasil Rinset Kesehatan Dasar (RISKESDAS) Nasional 2007. Badan Penelitian dan Pengembangan Kesehatan. Jakarta; 2008.

3. Harkati D. Aspek-aspek Epidemiologi Maloklusi. Cetakan Pertama. Gadjah Mada University Press. 1993. Yogyakarta

4. Dewi, O. Analisis Hubungan Maloklusi Dengan Kualitas Hidup Pada Remaja SMU Kota Medan Tahun 2007. Tesis. 2008. USU: Medan. http://repository.usu.ac.id/handle/1 23456789/669 Diakses tanggal 26 April 2013.

5. Budiharto. Metodologi Penelitian Kesehatan Dengan Contoh Bidang Ilmu Kesehatan Gigi. 2008. EGC. Jakarta 
6. Notoatmodjo, S. Prinsip-prinsip

Dasar Ilmu Kesehatan Masyarakat.

2003. Rineka Cipta. Jakarta

7. Notoatmodjo, S. Promosi

Kesehatan dan Ilmu Perilaku.

Cetakan Pertama. 2007. Rineka

Cipta. Jakarta

8. Gaol, Lumban Tiomarni. Tesis:

Pengaruh Faktor Sosiodemografi,

Sosioekonomi, dan Kebutuhan

Terhadap Perilaku Masyarakat

dalam Pencarian Pengobatan di

Kecamatan Medan Kota Tahun

2013. 2013.

9. Azwar. Sikap Manusia dan

Pengukurannya. 2002. Rineka

Cipta. Jakarta

10. Saragih, Christina. Skripsi: Pengaruh Faktor Sosial Ekonomi dan Sosiokultural Terhadap Demand Masyarakat Pada Pelayanan Pertolongan Persalinan di Puskesmas Pekan Labuhan Tahun 2003. http://repository.usu.ac.id/handle/1 23456789/32589. Diakses tanggal 26 April 2013. 